\title{
The Effect Of Student's Interest And Motivation To Final Score Of Methodology Of Research And Basic Statistic Subject At Sari Mulia Midwifery Academy
}

Selfana Lady Rosadi ${ }^{1 *}{ }^{1}$ STIKES Sari Mulia, Banjarmasin Indonesia

*selfana_lady_rosadi@stikessarimulia.ac.id

Sitti Khadijah ${ }^{2}$

${ }^{2}$ Academy of midwifery Sari Mulia Banjarmasin Indonesia

Sitti_khadijah@akbidsarimulia.ac.id

Herdiantri Sufriyana ${ }^{2}$

${ }^{2}$ Academy of midwifery Sari Mulia Banjarmasin Indonesia

herdiantri@gmail.com

\begin{abstract}
Objective: To analyze the influence of student's interest and motivation on the achievement of student learning outcomes in Basic Research and Statistics course at AKBID Sari Mulia.

Method: The research method used is an analytical survey with cross sectional approach. The population of the study were all 6th semester students of AKBID Sari Mulia Banjarmasin VIII. The sample was 67 people with sampling technique using proportional simple random sampling. The data were collected using questionnaire and statistical analysis with Spearman Rank correlation test $(\mathrm{p}=0.05)$.

Results: There was no influence between interest in achievement of learning outcomes $(p=0.489$ with confidence level of 95\%). There is no influence between motivation toward achievement of learning result ( $\mathrm{p}=0805$ with confidence level of $95 \%$ ).

Conclusion: Students recognize that each course has important benefits for present and for the future.
\end{abstract}

Keywords: Interest, Learning Outcomes, Motivation, Students

\section{INTORUDCTION}

Education is a conscious effort to cultivate the potential for human resources through teaching activities. Indonesia is one of the developing countries in the world that still has big problems of education.

In the international world Indonesia's education quality is ranked 69th out of 127 countries worldwide based on data obtained from Education For All (EFA) Global Monitoring Report 2011 released by
UNESCO launched in New York education development index or Education Development Index (EDI) based on 2008 data is 0.934 .

One of education in Indonesia is majoring in midwifery. Obstetrics Department is a gateway introduction to midwives to be ready to become professionals in entering the world of work.

Efforts to achieve learning outcomes or optimal academic achievement of the learning 
process, a student can be influenced by internal and external factors.

Learning outcomes is a result of one's learning process .Relate learning outcomes of a change in the person learning. The shape of the change as a result of learning in the form of changes in knowledge, understanding, attitudes and behavior, skills and abilities. Changes in the sense of changes caused by growth are not considered as learning outcomes. Changes as a result of learning are relatively permanent and have the potential to flourish [1].

Interest \& Motivation is internal factors that affect the achievement of learning outcomes. Hence the need for high learning interest and good motivation to achieve maximum learning outcomes [2].

In the education of DIII Midwifery in AKBID Sari Mulia Banjarmasin, student of class VIII uses the 2011 curriculum which must complete as many as 113 credits. One of them is the Methodology of Research and Basic Statistics Subject with a load of 3 SKS.

From the results of discussions conducted to some students, by asking what subjects they think to be a constraint in terms of value and understanding, students mentioned that the course is the Methodology of Research and Basic Statistics Subject.

From the preliminary study conducted to 10 students by asking whether the students are interested in the Methodology of Research and Basic Statistics Subject, only 2 students that said interested and 8 other students said not interested. In addition to asking about interest also asks student's motivation in studying the Methodology of Research and Basic Statistics Subject from 10 students, 2 students replied because this course will be useful for stock at research, and 8 other students say just to get the value in the course of Methodology of Research and Basic Statistics Subject.

Based on the data obtained from the list of students scores of 8 of the 199 students, 82 students (41.2\%) got scores (B-), 81 students (40.7\%) got a score of (B), 34 students (17.1 $\%)$ got the score $(\mathrm{B}+)$, and only 2 students (1\%) got the value (A-), so in this case it is necessary to do research to know the influence of student's interest and motivation to the achievement of student learning outcomes in the course of Methodology of Research and Basic Statistics Subject at AKBID Sari Mulia Banjarmasin.

\section{RESEARCH METHODS}

The research method used is an analytic survey using quantitative design with Cross Sectional approach. This research is done in Midwifery Academy Sari Mulia Banjarmasin.

The population used is all the students of AKBID Sari Mulia Banjarmasin VI VIII 6th semester class (A, B, C, and D) who have subjects of 199 Methodology of Research and Basic Statistict Subject. Technique of using sample using proportional simple random sampling with sample amount 
counted 67 students by using formula for Taro Yamane with Precision Level 0,1 [3]:

$$
\mathrm{n}=\frac{\mathrm{N}}{1+\mathrm{N}(\mathrm{d})^{2}}
$$

Number of samples per class (A, B, C, and D) so that the division of samples of each class is adequate, using the formula: Number of samples per starata $=($ Number of population per strata: Population number) $\mathrm{x}$ number of samples.

Table 1 Number of Samples Each Class Students Force

VIII Semester VI AKBID Sari Mulia

Banjarmasin

\begin{tabular}{cccc}
\hline Number & Class & Population & $\begin{array}{c}\text { Sampel } \\
\text { Prorportion }\end{array}$ \\
1 & A & $(51: 199) \times 67$ & 17 \\
2 & B & $(60: 199) \times 67$ & 20 \\
3 & C & $(46: 199) \times 67$ & 16 \\
4 & D & $(42: 199) \times 67$ & 14 \\
\hline
\end{tabular}

The variables of this study consist of independent variables (interest and motivation of students) and dependent variable (student learning outcomes).

Sources of data used are primary data (questionnaires) and secondary data (report learning outcomes Methodologyof Research and Basic Statistict Subject from the Evaluation AKBID Sari Mulia Banjarmasin).

Data analysis is done by several stages of checking data, giving code, entering data and last analyzing data using Spearman rank test of Alpha $=0.05$.
III. RESULT

1. Frequency Distribution of Final Score

Table 2 Distribution of Student Learning Outcomes

\begin{tabular}{ccc}
\hline $\begin{array}{l}\text { Learning } \\
\text { Outcomes }\end{array}$ & $\mathrm{N}$ & $\%$ \\
\hline $\mathrm{A}$ & 2 & 3 \\
$\mathrm{~B}$ & 65 & 97 \\
\hline & 67 & 100 \\
\hline
\end{tabular}

Based on Table two can be seen that of 67 Students who become respondents research, got the most students get a B of 65 people (97\%).

Frequency Distribution of Interest

Table 3 Student Interest Distribution

\begin{tabular}{ccc}
\hline Interest & $\mathrm{N}$ & $\%$ \\
\hline Low & 13 & 19,4 \\
High & 54 & 80,6 \\
\hline & 67 & 100 \\
\hline
\end{tabular}

Based on Table three can be seen that of 67 Students who become respondents research, got the most students have a high interest amounted to 54 people $(80.6 \%)$.

Frequency Distribution of Motivation

Table 4 Student Motivation Distribution

\begin{tabular}{ccc}
\hline Motivation & $\mathrm{N}$ & $\%$ \\
\hline Low & 2 & 3 \\
High & 65 & 97 \\
\hline & 67 & 100 \\
\hline
\end{tabular}

Based on Table four it can be seen that from 67 Students who become respondents research, got the most students have high motivation amounted to 65 People (97\%).

2. The influence of interest in the achievement of student learning 
outcomes of the Methodology of Research and Basic Statistict Subject at Sari Mulia Midwifery Academy.

Table 5 Interest Distribution of Respondents to the

\begin{tabular}{lccccccc}
\multicolumn{4}{c}{ achievement of student learning outcomes } \\
\hline \multirow{3}{*}{ Intereset } & \multicolumn{3}{c}{ Learning Outcomes } & \multicolumn{2}{l}{ Total } \\
& $\mathrm{A}$ & & \multicolumn{3}{c}{$\mathrm{B}$} & \multicolumn{2}{l}{} \\
& $\mathrm{N}$ & $\%$ & $\mathrm{~N}$ & $\%$ & $\mathrm{~N}$ & $\%$ \\
\hline Low & 0 & 0 & 13 & 19.4 & 13 & 19.4 \\
High & 2 & 3 & 52 & 77.6 & 54 & 80.6 \\
\hline & 2 & 3 & 65 & 97 & 67 & 100 \\
\hline
\end{tabular}

Based on Table five it can be seen that from 67 Students that become research respondents got students who have High Interest and Learning Outcomes amounted to two people (3\%). Students with Low Interest and Learning Outcomes B were 13 (19.4\%), and Students with High Interest and Learning B resulted 52 people (77.6\%).

The result of statistical analysis with Spearman Rank Correlation test got $\mathrm{p}$ value $(p$ value $)=0,489$, so $p>0,05$. This shows that "there is no influence over the interest in the achievement of student learning outcomes of the Methodology of Research and Basic Statistics Subject in AKBID Sari Mulia Banjarmasin".

3. The influence of motivation on the achievement of student learning outcomes of the Methodology of Research and Basic Statistics Subject in AKBID Sari Mulia Banjarmasin.
Table 6 Distribution of Respondents's Motivation to he achievement of student learning outcomes

\begin{tabular}{llllllll}
\hline \multirow{2}{*}{ Motivation } & \multicolumn{2}{c}{ Learning Outcome } & \multicolumn{2}{c}{ Total } \\
& \multicolumn{2}{c}{$\mathrm{A}$} & \multicolumn{2}{c}{$\mathrm{B}$} & \multicolumn{2}{c}{} \\
& $\mathrm{N}$ & $\%$ & $\mathrm{~N}$ & $\%$ & $\mathrm{~N}$ & $\%$ \\
\hline Low & 0 & 0 & 2 & 3 & 2 & 3 \\
High & 2 & 3 & 63 & 94 & 65 & 97 \\
\hline & 2 & 3 & 65 & 97 & 67 & 100
\end{tabular}

Based on Table six it can be seen that of 67 Students who become respondents research. It was found that students who have High Motivation and Learning Outcome amounted to two people (3\%). Students who have Low Motivation and Learning Outcomes B are 2 (3\%), and Students with High Motivation and Learning Outcomes are 63 People (94\%).

Result of statistical analysis with Spearman Rank Correlation tests got value $p(p$ value $)=0,805$, so $p>0,05$. This shows that "there is no influence over the motivation on the achievement of student learning outcomes of the course of Methodology of Research and Basic Statistics at AKBID Sari Mulia Banjarmasin".

\section{DISCUCCION}

1. Learning Outome

The results of research conducted in AKBID Sari Mulia Banjarmasin with 67 students that become research respondents, obtained the result that most of the students got $B$ value amounted to 65 people (97\%). 
The result of this research is got D III midwifery student of AKBID Sari Mulia Banjarmasin, that there is 65 students that get $\mathrm{B}$ value. This is because there are 2 factors that can influence student's learning result that is Internal factor of physiology (physiology, sensory) interest, and motivation), and external factors from the environment (natural, sociocultural), from the instrumental (curriculum, program, facilities and facilities, lecturers).

\section{Interest}

The results of research conducted in AKBID Sari Mulia Banjarmasin with 67 students that become research respondents, obtained the result that the majority of students have high interest amounted to 54 people (80.6\%).

From the research result, most of the students have high interest. People who are interested in a thing will pay attention not only lasting once but will repeatedly. High interest will spur someone to stay diligent to follow things considered interesting. With this interest will lead to perseverance to learn so it can spur to improve achievement in learning.

Based on the results of research conducted by Schiefele shows that the importance of interest depth understanding of text, the use of learning strategies, and the quality of emotional experience while learning [4]. So it can be concluded that someone who has interest will easily follow the learning process and will have an impact to the learning outcomes.

3. Motivation

The results of research conducted in AKBID Sari Mulia Banjarmasin with 67 students that become research respondents, obtained the result that most students have high motivation amounting to 65 people $(97 \%)$.

According to research conducted by Lunenburg states that the theory of motivation goal-setting is well-developed because it emphasizes the important relationship between goals and performance. The most effective performance will result when goals are specific and challenging. The impact on motivation from goals can be influenced by ability and self-eficacy [5]. Can be concluded that someone who has the ability is a verb made into a noun. They often need extra words to make sense. Strong verbs are easier to read and use less words will generate motivation.

From the research result most of the student have high motivation. This will have an impact on the results of student achievement because of the high learning motivation will support high learning results as well.

4. The influence of interest in the achievement of student learning outcomes 
The result of statistical analysis got $p$ value $(p$ value $)=0,489$ so $p>0,05$. This shows that there is no influence over the interest in the achievement of student learning outcomes of the course of Methodology of Research and Basic Statistics at AKBID Sari Mulia Banjarmasin.

The results of this study are also very different from previous studies which say that interest influences on learning achievement. As the research conducted by Budianto concluded that there is a significant influence of intrinsic learning motivation and interest in learning together towards student achievement. This difference is probably due to the characteristics of the samples taken differently between the previous studies and the current research. Budianto's research used a sample of educational background S1-Office Administration, while in this study the sample used is with D3-midwifery education background. This study used questionnaires with closed questionnaires so that respondents only gave answers to available alternative questions [6]. In the research questionnaire, there are students that have a low learning interest but good learning outcomes, in contrast to the theory put forward by Dalyono (1997) in Djamarah that if a student has a great interest in learning to tend to produce high achievement, will result in low achievement, so if it is related to the theory put forward by Dalyono (1997) in Djamarah it can be concluded that not only interest that can influence the learning outcomes there may be other factors that can influence [2]

Factors( Where possible you should use a simple word over a complex word. Simple words are easier to read and let your readers focus on your ideas

Replace factor with

- Reason

- Cause

that may affect the learning outcomes include internal factors and external factors. The environment is an external factor that can affect the learning outcomes. The environment here is not only the environment within the campus, at home but also about how the student association in the community. A conducive residential environment will encourage a person to learn quietly so that it can affect learning outcomes, as well as with a good campus environment will increase the concentration in learning so that the absorption is increasing. Students who in their daily circumstances mingle with friends that are categorized as lazy then the student will tend to become lazy so that the achievement achieved by the student will not be maximal. Because the sample used in this study has different environments, for example there are students who live with parents, and there are students who live in 
boarding places or dikontrakan. In line with research conducted by Saputro stated that there is a positive and significant influence of Peer Environment on Student Achievement. And for to peer environment contributes to the increase and decrease of learning achievement by $18.4 \%$ [7].

In addition to the environment, facilities and infrastructure also affect the learning outcomes. Lesson tools are less complete make the presentation of lessons is not good. The condition of the building, especially classrooms, quiet classrooms, cool, clean, and far away from crowded places will make it easier for children to concentrate [8].

Not only the environment and facilities and infrastructure that become external factors that can affect learning outcomes. Lecturers also have an important(A hidden verb (aka nominalization) is a verb made into a noun. They often need extra words to make sense. Strong verbs are easier to read and use less words.

You should revise have an important to bring out the verb) role in the acquisition of student learning outcomes. Based on the results of discussions conducted with 2 students, it is concluded that lecturers provide an important role in the continuity( Try to revise in the acquisition of with acquire or get)of teaching and learning process. "If the lecturer only gives an explanation for giving an example let alone learning about the analysis makes the students do not understand and over time will be bored(Use passive voice when the sentence object is more important than the subject. The active voice is generally easier to read)to follow the lesson and finally no longer pay attention to the lecturer who explained" a remark from one of the students. In line with the journal published by Sulastri with the results of the study showed that there is a very strong correlation between the learning achievement and the role of the lecturer with the value of $r=1$, and there is an influence of the lecturer's role, the facilities, the parents and the independence of the learning achievement [9].

Lecturers who teach by unfavorable methods will affect student learning is not good. Ordinary lecturers teach by lecture method only, making students become bored, drowsy, passive and just take notes. In order for students to learn well, then teaching methods should be cultivated appropriate, efficient, and effective [10].

An important role is held by a lecturer not only in the selection of learning modes that can influence the learning outcomes. In Pingge Research it is explained that there is a positive and significant correlation between teacher competence in diagnosing learning difficulties, utilizing learning media and managing the classroom with improving student learning outcomes [11]. 
5. Influence Motivation on achievement of student learning outcomes

The result of statistical analysis got $\mathrm{p}$ value $(\mathrm{p}$ value $)=0,805$, so $\mathrm{p}>0,05$. This shows that there is no influence over the motivation to the achievement of student learning outcomes of the course Methodology of Research and Basic Statistics at AKBID Sari Mulia Banjarmasin.

The results of this study in line with research conducted by Adirestury which states that the motivation to learn does not affect student achievement. No effect on the motivation of learning achievement due to many other fatkor that have greater influence. As revealed by Gagne and Berliner who written Adirestury that academic achievement is strongly influenced by peers. If the friend shows negative attitude to the students that have high motivation in learning, then the possibility of students will decrease their learning level to be accepted by the play group so it can lowered student achievement [12].

The results of this study inversely proportional to the results of research Battle reveals motivation to contribute to the prediction of IQ [13]. IQ is an assessment indicator to express learning outcomes. In addition, based on the results of research Singh said the results support the posited effects of two motivational factors, attitudes and academy time to mathematics and science achievement [14].

In heory of learning outcomes Djamarah mentions that there are factors that can affect the results of learning factors both internal and external factors. Motivation is an internal factor that can affect student learning outcomes [2].

In the existing research questionnaires, there are students that have low motivation but the learning outcomes 77, while students that have high motivation but the results of learning 69 it has illustrated that there is no influence over motivation and learning outcomes. Possible many other things that can affect learning outcomes. Because in this study there are still many deficiencies in the samples used in this study only take $1 / 3$ of the total population, so for the results obtained can not generalized in general.

The results of this study are inversely proportional to the results of research conducted by Warti mentions that there is a positive relationship between the motivation of(Try to revise the motivation of with motivate or impelled action.) learning with the results of learning mathematics. Differences in the results of this study can also be related to the sample conditions which in the study conducted by Warti using a sample of children who are still sitting in primary 
school, while in this study using student samples. Give the differences in character of this sample, this is what triggers the difference in the results of the study [15].

Physiological conditions in general are very influential on one's learning ability. A person that is physically fit will learn differently from a person that is exhausted. Similarly, the condition of the senses, especially the eyes as a tool to see and ears as a tool to hear. So the importance of the role of vision and hearing is because most of the learning activities undertaken by students by reading, listening, and doing observasi. This is strongly supported by research conducted by Hendikawati with the results of research shows that there are 5 factors that influence student achievement index, these factors include self-management factors, environmental factors, external factor, physical condition factor and sport factor. Among the 5 factors the physical condition is one of the factors that influence learned outcomes [16].

In addition to the physiological conditions of cognitive ability also gives effect of learning outcomes. Students who are essentially smart, will be faster and more understandable in mastering the lecture materials, while students who have below average skills will have little difficulty to understand the lecture material. Cognitive domain is a capability that is always required to learners to master, because the assignment to the ability at this level become the basis of mastery of science. In line with research conducted by Juniar with the results of the study mentioned that the type of test and cognitive ability affect the learning outcomes [17].

Same with the research conducted by Putri explained that the motivation has no direct effect on the learning result because of many other factors that can influence the learning outcomes such as health, intelligence, talent, way of learning and the people around it that can give effect [18].

\section{CONCLUSION}

Based on the result of the research and the result of the discussion, it can be concluded that there is no influence between the interest toward the achievement(Try to revise the achievement of with achieve.) of student learning outcomes in the Methodology of Research and Basic Statistics Subject in AKBID Sari Mulia Banjarmasin, with $p$ value $(p$ value $)=0,489, \%$, so $p>0,05$, and there is no influence between the motivation to the achievement of student learning outcomes in the Methodology of Research and Basic Statistics Subject in AKBID Sari Mulia Banjarmasin, with p value $(p$ value $)=0,805$, with confidence level 95\% so $\mathrm{p}>0,05$. 


\section{REFERENCES}

[1]. Lestari, Indah. Pengaruh Waktu Belajar Dan Minat Belajar Terhadap Hasil Belajar. Matematika. Jurnal Formatif, 3(2): 115-125; 2013.

[2]. Djamarah, Syaiful Bahri. Psikologi Belajar. Jakarta : Rineka Cipta ; 2011.

[3]. Riduwan, Akdon. Rumus dan Data dalam Aplikasi Statistika. Bandung : Alfabeta ; 2010.

[4]. Schiefele, Ulrich. Interest, Learning and Mptivation. Journal Educational Psychologist Vo.26, Issue 3-4 : 1991.

[5]. Lunenburg, Fred C. Goal-Setting Theory of Motivation. International Journal of Management Business and Administration Vol.15. Number 1 : 2011.

[6]. Budianto, Arif. Pengaruh Motivasi Belajar Instrinsik dan Minat Belajar terhadapPrestasi Belajar Mahasiswa Pendidikan Administrasi Perkantoran Angkatan 2010 FE UNY. Skripsi. Yogyakarta : FE UNY ; 2012.

[7]. Saputro, Singgih Tego. Pengaruh Disiplin Belajar dan Lingkungan Teman Sebaya terhadap Prestasi Belajar Mahasiswa PRODI Pendidikan Akutansi Angkatan 2009 FE UNY. Skripsi. Yogyakarta : FE UNY ; 2012.

[8]. Khairani, Makmun. Psikologi Belajar. Yogyakarta : Aswaja Pressindo ; 2013.

[9]. Sulastri, Reni Endang. Pengaruh Dosen, Fasilitas, Orang Tua dan Kemandirian terhadap Kualitas BelajarMahasiswa Politeknik NegeriPadang. Jurnal R \& B, 2 (2) ; 2012.

[10]. Slameto. Belajar dan faktor-faktor yang mempengaruhinya. Jakarta : Rineka Cipta ; 2010.

[11]. Pingge, Heronisu Delu. Wangid, Muhammad Nur. Faktor yang
Mempengaruhi Hasil Belajar Siswa Sekolah Dasar di Kecamatan Kota Tambolaka.. Jurnal Pendidikan Sekolah Dasar Vol.2, No.1 ; 2016.

[12]. Adirestury, Fitranty. Pengaruh SelfEfficacy Guru dan Kreativitas Guru Terhadap Motivasi Belajar Siswa dan Implikasinya terhadap Prestasi Belajar pada Mata Pelajaran Ekonomi. SOSI DIDAKTIKA : Social Sciense Education Journal, Vol.3. No.2 ; 2016.

[13]. E. Battle. Motivational determinants of academic competence. Journal of Personality and Social Psychology, 4 (1966), pp. 534-642

[14]. Singh, Kusum. Granville, Monique. Dika, Sandra. Mathematics and Science Achievement: Effects of Motivation, Interest, and Academic Engagement . The Journal of Educational Research, 6th ed, Vol 95: 2002, pp. 323-332.

[15]. Warti, Elis. Pengaruh Motivasi Siswa terhadap Hasil Belajar Matematika Siswa di SD Angkasa 10 Halim Perdana Kusuma Jakarta Timur. Jurnal Mosharafa, Vol 8, Nomor 3 : 39-47 ; 2016.

[16]. Hendikawati, Putriaji. Analisis Faktor yang mempengaruhi Indeks Prestasi Mahasiswa. Skripsi. Semarang : Unnes Sekaran Gunungpati. 2011.

[17]. Juniar, Nita. Pengaruh Tes dan Kemampuan Kognitif terhadap Hasil Belajar Materi Sistem Peredaran Darah. 2014. Diakses dalam http://download.portalgaruda.org.

[18]. Putri, Dinar Tiara Nadip. Isnani, Gatot. Pengaruh Minat dan Motivasi terhadap Hasil Belajar pada Mata Pelajaran Administrasi Perkantoran. Jurnal Pendidikan Bisnis dan Manajemen, Vol.1, No.2 : 2015. 